\title{
Povećanje brzine oslobađanja lurasidon-hidroklorida iz raspadljivih tableta za usta primjenom liofilizacije
}

\author{
J. Skočibušić, J. Barbarić*i K. Žižek \\ Fakultet kemijskog inženjerstva i tehnologije, Marulićev trg 19, 10000 Zagreb
}

\begin{abstract}
Sažetak
U ovom radu istražuju se mogućnosti povećanja brzine oslobađanja lurasidon-hidroklorida, antipsihotika druge generacije, pripravom čvrstih disperzija procesom liofilizacije. FTIR, DSC te XRPD ispitivanja provedena su s ciljem detekcije potencijalnih interakcija između lurasidon-hidroklorida i polimernih matrica koje mogu znatno povećati topljivost djelatne tvari i osigurati brže oslobađanje iz dozirnog oblika. Takve čvrste disperzije i pomoćne tvari upotrijebljene su u pripravi tableta čija su vremena raspadanja manja od $3 \mathrm{~min}$. Profili otapanja u laboratorijskom okruženju ukazuju na brže oslobađanje djelatne tvari iz raspadljivih tableta u odnosu na čisti lurasidon-hidroklorid.
\end{abstract}

\section{Ključne riječi}

Lurasidon-hidroklorid, čvrsta disperzija, liofilizacija, raspadljiva tableta za usta, oslobađanje djelatne tvari

\section{Uvod}

Shizofrenija i bipolarni poremećaj s maničnim ili depresivnim epizodama teške su psihičke bolesti današnjice visokih prevalencija, podjednako u ženskoj i muškoj populaciji. ${ }^{1} U$ liječenju tih psihičkih poremećaja upotrebljavaju se antipsihotici, prve i druge ili novije generacije. $^{2} U$ ovom radu istražuje se i formulira antipsihotik novije generacije, lurasidon-hidroklorid (LRS $\mathrm{HCl}$ ), danas dostupan na tržištu u dozirnom obliku konvencionalnih tableta Latuda ${ }^{\circledR}$.

Pridržavanje propisane terapije važan je parametar u uspješnom liječenju svih bolesnika. Mnogi pacijenti, posebno psihijatrijski, ne pridržavaju se uputa o redovitom i striktnom konzumiranju propisane terapije. Posljedice nepridržavanja terapije $u$ toj skupini bolesnika podrazumijevaju prisutnost zaostalih simptoma, oslabljeno psihosocijalno ponašanje, visoku stopu samoubojstava i česte recidive. ${ }^{3}$ Uzevši u obzir navedeno, ne čudi činjenica da su raspadljive tablete za usta (engl. orally disintegrating tablets, ODTs), kao relativno nov i atraktivan dozirni oblik, privukle znatnu pažnju u akademskim i istraživačkim zajednicama. Američka Agencija za hranu i lijekove (engl. Food and Drug Administration, FDA) definira raspadljive tablete kao čvrsti dozirni oblik lijeka koji sadrži djelatne tvari koje se u usnoj šupljini raspadaju brzo, obično u roku od oko 30 sekundi ili manje. ${ }^{4}$ Europska farmakopeja (engl.
European Pharmacopoeia, Ph. Eur.) definira ih kao neobložene tablete koje se stavljaju u usta gdje se brzo, prije gutanja, dispergiraju te kao tablete koje bi se trebale razgraditi unutar 3 min. ${ }^{5}$ Raspadljive tablete pokazuju se kao bolje terapijsko rješenje u liječenju mnogih skupina bolesnika od tradicionalnih čvrstih dozirnih oblika za oralnu primjenu lijeka (konvencionalne tablete ili kapsule).

Kao i mnogi drugi novosintetizirani kemijski entiteti, lurasidon-hidroklorid je djelatna tvar niske topljivosti u vodenom mediju. lako ima izvrsnu propusnost kroz crijevnu membranu, to svojstvo slabe topljivosti dovodi do otežane apsorpcije lijeka u organizmu i usporenog farmakološkog djelovanja. ${ }^{6,7}$ Kao posljedica slabe topljivosti lurasidon-hidroklorida javlja se i niska bioraspoloživost $(9-19 \%)$ te ukupno nepovoljan terapijski učinak lijeka. Zbog svega navedenog, primjena te djelatne tvari u liječenju poremećaja, kada je nužno osigurati brzo farmakoterapijsko djelovanje (poput napadaja shizofrenije i manije), znatno je otežana. U povećanju topljivosti djelatnih tvari primjenjuju se različiti pristupi. ${ }^{8}$ Značajne prednosti i dobre rezultate u povećanju topljivosti pokazuje pristup priprave čvrstih disperzija ${ }^{6,9-11}$ odnosno sustava čvrstoga u kojima je djelatna tvar (ili više njih) bolje ili lošije dispergirana, po mogućnosti na molekulskoj razini, u matrici hidrofilnog polimera.

Ovim istraživanjem, nastoje se pripraviti raspadljive tablete s povećanom topljivosti i brzinom oslobađanja lurasidon- 
hidroklorida. U pripravi raspadljivih dozirnih oblika primjenjuje se tabletiranje, a u povećanju topljivosti pristup priprave disperzija. Čvrste disperzije pripravljaju se procesnom tehnologijom liofilizacije, a kao testne matrice upotrebljavaju se hidrofilni polimeri poli(etilen-glikol) (PEG) i hidroksipropil-metil-celuloza (HPMC).

U karakterizaciji disperzija primjenjuju se analitičke tehnike kojima se uspješno detektiraju svojstva dokazanog i značajnog učinka na topljivost tvari, ali i dokazuje uspješna priprava disperzija. Uzorci disperzija različitih sastava karakterizirat će se diferencijalnom pretražnom kalorimetrijom, rendgenskom difrakcijskom analizom praha i infracrvenom spektroskopijom s Fourierovim transformacijama.

Raspadljivi dozirni oblici lijeka, s čvrstim disperzijama i bez njih, pripravljaju se tabletiranjem te testiraju na svojstva karakteristična i propisana za ovakav dozirni oblik: ujednačenost masa, tvrdoća, raspadljivost i sadržaj djelatne tvari. Ispitivanjima in vitro testira se topljivost djelatne tvari te utvrđuju profili njezina oslobađanja iz raspadljivih tableta.

\section{Eksperimentalni dio}

\subsection{Materijali}

Svi upotrijebljeni materijali i njihova uloga u pojedinom segmentu provedbe istraživanja navedeni su u tablici 1.

\subsection{Priprava uzoraka}

\subsubsection{Priprava čvrstih disperzija postupkom liofilizacije (sušenja smrzavanjem)}

Provedbi liofilizacije prethodila je priprava otopina djelatne tvari i polimera različitog sastava u 50 \%-tnom vodeno-etanolnom otapalu. Pripravljene su otopine definiranih masenih odnosa djelatne tvari i polimera i to kako slijedi: LRS HCl-PEG 1:1, LRS HCl-HPMC $1: 1$ te LRS HCl-PEG-HPMC $2: 1: 1$. Otopine su potom smrznute u kapljevitom dušiku te podvrgnute sušenju. Postupak liofilizacije proveden je na uređaju Kambič LIO-5 PLT (Kambič d.o.o., Semič, Slovenija) pri temperaturi od $-100{ }^{\circ} \mathrm{C}$ i tlaku od 0,2 mbar u trajanju $50 \mathrm{~h}$.

\subsubsection{Priprava raspadljivih tableta za usta}

Mješavine za tabletiranje u kojima ciljani sadržaj LRS HCl iznosi 10 mas. \% pripravljene su umješavanjem čvrstih disperzija i pomoćnih tvari u porculanskom tarioniku. S ciljem definiranja točne mase čvrste disperzije potrebne za pripravu mješavine ciljanog sastava, sadržaj LRS HCl u svim

Tablica 1 - Popis kemikalija upotrijebljenih u istraživanju

Table 1 - List of chemicals used in the research

\begin{tabular}{|c|c|c|}
\hline $\begin{array}{l}\text { Kemikalija } \\
\text { Chemical }\end{array}$ & $\begin{array}{l}\text { Uloga } \\
\text { Function }\end{array}$ & $\begin{array}{l}\text { Dobavljač } \\
\text { Supplier }\end{array}$ \\
\hline \multicolumn{3}{|c|}{$\begin{array}{l}\text { Priprava čvrstih disperzija } \\
\text { Preparation of solid dispersions }\end{array}$} \\
\hline $\begin{array}{l}\text { lurasidon-hidroklorid } \\
\text { (LRS } \mathrm{HCl} \text { ) } \\
\text { lurasidone } \\
\text { hydrochloride (LRS } \\
\mathrm{HCl} \text { ) }\end{array}$ & $\begin{array}{l}\text { djelatna tvar } \\
\text { active } \\
\text { pharmaceutical } \\
\text { ingredient }\end{array}$ & $\begin{array}{l}\text { TAPI Hrvatska d. o. o. } \\
\text { (Zagreb, Hrvatska) }\end{array}$ \\
\hline $\begin{array}{l}\text { poli(etilen-glikol) } \\
\text { (PEG) } 4000 \\
\text { polyethylene glycol } \\
\text { (PEG) } 4000\end{array}$ & $\begin{array}{l}\text { polimerna matrica } \\
\text { polymer matrix }\end{array}$ & $\begin{array}{l}\text { Acros Organics } \\
\text { (New Jersey, SAD) }\end{array}$ \\
\hline
\end{tabular}

hidroksipropil-metil-

celuloza

(HPMC) E-6 2910

hydroxypropyl

methylcellulose

(HPMC) E-6 2910

etanol $96 \%$, p.a.

polimerna matrica polymer matrix

JRS Pharma

(Rosenberg, SR

Njemačka)

\section{ethanol $96 \%$, p.a. \\ Granuliranje pomoćnih tvari \\ Granulation of excipients \\ Gralation of excipients}

mikrokristalna

celuloza PH 102,

(MCC)

microcrystalline

cellulose PH 102,

(MCC)

\begin{tabular}{|c|c|c|}
\hline $\begin{array}{l}\text { manitol (MAN) } \\
\text { mannitol (MAN) }\end{array}$ & $\begin{array}{l}\text { punilo } \\
\text { filler }\end{array}$ & $\begin{array}{l}\text { Pliva Hrvatska d. o. o. } \\
\text { (Zagreb, Hrvatska) }\end{array}$ \\
\hline $\begin{array}{l}\text { natrijeva } \\
\text { kroskarmeloza (NKK) } \\
\text { croscarmellose } \\
\text { sodium (CCS) }\end{array}$ & $\begin{array}{l}\text { sredstvo za } \\
\text { raspadanje } \\
\text { disintegrant }\end{array}$ & $\begin{array}{l}\text { Pliva Hrvatska d. o. o } \\
\text { (Zagreb, Hrvatska) }\end{array}$ \\
\hline \multicolumn{3}{|c|}{$\begin{array}{l}\text { Tabletiranje } \\
\text { Tableting }\end{array}$} \\
\hline $\begin{array}{l}\text { magnezijev stearat } \\
\text { magnesium stearate }\end{array}$ & $\begin{array}{c}\text { sredstvo za kliženje } \\
\text { lubricant }\end{array}$ & $\begin{array}{l}\text { Pliva Hrvatska d. o. o } \\
\text { (Zagreb, Hrvatska) }\end{array}$ \\
\hline \multicolumn{3}{|c|}{$\begin{array}{l}\text { Određivanje sadržaja LRS HCl } \\
\text { Determination of LRS } \mathrm{HCl} \text { content }\end{array}$} \\
\hline $\begin{array}{l}\text { metanol, p.a. } \\
\text { methanol, p.a. }\end{array}$ & $\begin{array}{l}\text { otapalo } \\
\text { solvent }\end{array}$ & $\begin{array}{c}\text { Lachner. } \\
\text { (Neratovice, Češka } \\
\text { Republika) }\end{array}$ \\
\hline \multicolumn{3}{|c|}{$\begin{array}{l}\text { Oslobađanje LRS } \mathrm{HCl} \text { iz raspadljivih tableta } \\
\text { Release of LRS } \mathrm{HCl} \text { from ODTs }\end{array}$} \\
\hline $\begin{array}{l}\text { dinatrijev hidrogen } \\
\text { fosfat, p.a. } \\
\text { disodium hydrogen } \\
\text { phosphate, p.a. }\end{array}$ & $\begin{array}{c}\text { sol za otopinu pufera } \\
\text { buffer solution salt }\end{array}$ & $\begin{array}{c}\text { Lachner. } \\
\text { (Neratovice, Češka } \\
\text { Republika) }\end{array}$ \\
\hline $\begin{array}{l}\text { limunska kiselina, } \\
\text { p.a. } \\
\text { citric acid, p.a. }\end{array}$ & $\begin{array}{c}\text { sol za otopinu pufera } \\
\text { buffer solution salt }\end{array}$ & $\begin{array}{l}\text { Gram-Mol d. o. o. } \\
\text { (Zagreb, Hrvatska) }\end{array}$ \\
\hline
\end{tabular}

Pliva Hrvatska

d. o. o.

(Zagreb, Hrvatska)

\begin{tabular}{c|c}
$\begin{array}{c}\text { punilo } \\
\text { filler }\end{array}$ & d. O. O. \\
& (Zagreb, Hrvatska)
\end{tabular}

Kefo d. o. o.

jubljana, Slovenija)

punilo

punilo Pliva Hrvatska d. o.

sredstvo za Pliva Hrvatska d.o.o. 
Čvrstim disperzijama određen je primjenom metode opisane u poglavlju 2.4.2.

Pomoćne tvari navedene $\mathrm{u}$ tablici 1 prethodno su okrupnjene granuliranjem u fluidiziranom sloju s taljenjem, a sam postupak proveden je u granulatoru Uni-Glatt (Glatt GmbH, Binzen, SR Njemačka). PEG 4000 (2 mas. \% na ukupno granuliranu masu) upotrijebljen je kao vezivna tvar, a granuliranje je provedeno pri sljedećim procesnim uvjetima: volumni protok zraka za fluidizaciju $3 \times 10^{-2} \mathrm{~m}^{3} \mathrm{~s}^{-1}$, temperatura ulaznog zraka $90^{\circ} \mathrm{C}$, veličina čestica vezivne tvari 90-125 $\mu \mathrm{m}$. Dobiveni granulat prosijavanjem je razdijeljen na različite veličinske frakcije, pri čemu su granule veličinskog razreda $200-500 \mu \mathrm{m}$ upotrijebljene u pripravi mješavina za tabletiranje.

Raspadljive tablete za usta pripravljene su komprimiranjem mješavina različitih sastava (tablica 2) na uređaju za tabletiranje TDP-5T (Zhejiang Wisely Machinery Co. Ltd. Zhejiang, NR Kina) uz dodatak magnezijeva stearata. Upotrijebljena je okrugla matrica promjera $8 \mathrm{~mm}$.

Tablica 2 - Sastavi mješavina za tabletiranje

Table 2 - Tableting mixtures composition

\begin{tabular}{|c|c|c|c|}
\hline \multicolumn{4}{|c|}{$\begin{array}{c}\text { Mješavina za tabletiranje } \\
\text { Tableting mixture }\end{array}$} \\
\hline & LRS-PEG & LRS-HPMC & LRS-PEG-HPMC \\
\hline $\begin{array}{l}\text { Sastojak } \\
\text { Component }\end{array}$ & \multicolumn{3}{|c|}{ mas. \% } \\
\hline MAN & 59,28 & 59,28 & 59,28 \\
\hline $\begin{array}{l}\text { MCC PH } \\
102\end{array}$ & 14,80 & 14,80 & 15,80 \\
\hline $\begin{array}{l}\text { NKK } \\
\text { CCS }\end{array}$ & 3,68 & 3,68 & 3,68 \\
\hline $\begin{array}{l}\text { HPMC } 2910 \\
\text { E-6 }\end{array}$ & - & 10,00 & 5,00 \\
\hline PEG 4000 & 12,40 & 2,40 & 7,40 \\
\hline LRS HCl & 10,00 & 10,00 & 10,00 \\
\hline
\end{tabular}

\subsection{Karakterizacija čvrstih disperzija}

\subsubsection{Diferencijalna pretražna kalorimetrija (DSC)}

DSC analiza provedena je na približno $5 \mathrm{mg}$ uzoraka odvaganih $\mathrm{u}$ aluminijske posudice $\mathrm{s}$ probušenim poklopcem. Mjerenja su provedena u struji dušika pri protoku od $60 \mathrm{~cm}^{3} \mathrm{~min}^{-1}$ te brzinom zagrijavanja od $10{ }^{\circ} \mathrm{C} \mathrm{min}^{-1} \mathrm{u}$ temperaturnom području od 0 do $360^{\circ} \mathrm{C}$ na uređaju Mettler Toledo DSC823e (Mettler-Toledo AG, Greifensee, Švicarska Konfederacija).

\subsubsection{Infracrvena spektroskopija s} Fourierovom transformacijom

FT-IR spektri snimljeni su ATR-FTIR spektrofotometrom Bruker Vertex $60 \mathrm{~s}$ platinastim detektorom (Bruker, Billerica, Sjedinjene Američke Države) u području valnih brojeva od 4500 do $500 \mathrm{~cm}^{-1}$ uz spektralnu rezoluciju od $2 \mathrm{~cm}^{-1}$. Uzorke čvrstih disperzija nije bilo potrebno dodatno pripremati, već su izravno postavljeni na podlogu za mjerenje. Provedena su 32 pojedinačna mjerenja svakog uzorka, a dobiveni FT-IR spektri njihova su srednja vrijednost.

\subsubsection{Rendgenska difrakcijska analiza praha (XRPD)}

Identifikacija faznog sastava čistih komponenti i čvrstih disperzija provedena je rendgenskom difrakcijom praha na uređaju Shimadzu XRD 6000 (Shimadzu, Kyoto, Japan) s Cu-Ko izvorom zračenja valne duljine, $\lambda=1,54059 \AA$. Primijenjen je napon od $40 \mathrm{kV}$ i jakost struje $30 \mathrm{~mA}$. Podatci su prikupljeni između $2 \theta=5-50^{\circ}$, s korakom od $0,02^{\circ}$ i zadržavanjem od 0,6 s po koraku.

\subsection{Karakterizacija raspadljivih tableta za usta}

\subsubsection{Ispitivanje ujednačenosti masa, tvrdoća i raspadljivosti tableta}

Ujednačenost masa ispitana je na deset nasumično odabranih tableta istog uzorka upotrebom analitičke vage KERN ALJ 220-4NM (KERN, Balingen, SR Njemačka).

Ispitivanja tvrdoće provedena su na uređaju Erweka TBH 325 u tvrtki Dechra Pharmaceuticals. Izračunata je prosječna vrijednost sila potrebnih za lomljenje 10 pojedinačnih tableta. ${ }^{12}$

Testovi brzine raspadanja tableta provedeni su u skladu $\mathrm{s}$ metodom propisanom europskom farmakopejom, Ph. Eur. 2.9.1. Ispitivani medij je destilirana voda zagrijana na $37^{\circ} \mathrm{C}$, a analiza je provedena na šest tableta istodobno. Ispitivanje je provedeno na uređaju Erweka ZT 322 (Erweka GmbH, Langen, SR Njemačka). ${ }^{13}$

\subsubsection{Određivanje sadržaja djelatne tvari}

Sadržaj djelatne tvari u pripravljenim tabletama određen je primjenom UV/Vis spektrofotometrijske metode na deset nasumično odabranih tableta svakog uzorka. Nakon usitnjavanja u tarioniku tablete su prenesene u odmjerne tikvice nadopunjene metanolom. Sadržaj svake tikvice filtriran je PTFE membranskim filtrima promjera pora $0,45 \mu \mathrm{m}$. Prikladno razrijeđenim uzorcima apsorbancija LRS $\mathrm{HCl}$ određena je pri valnoj duljini $\lambda \approx 315,0 \mathrm{~nm}$ te izračunata njegova koncentracija. 


\subsubsection{Oslobadanje djelatne tvari}

Testovi oslobađanja djelatne tvari in vitro provedeni su u skladu s propisanom metodom za LRS $\mathrm{HCl}$ formuliran $\mathrm{u}$ obliku tableta (metoda USPII). Ispitivanja su trajala $120 \mathrm{~min}$, pri brzini okretanja lopatica od $50 \mathrm{~min}^{-1}$ i temperaturi $37^{\circ} \mathrm{C}$. Analiza je provedena na uređaju Dissolution tester RC-6D (Zhengzhou Nanbei Instrument Equipment, Zhengzhou, NR Kina), u $900 \mathrm{ml}$ Mcllvaineova pufera $\mathrm{pH}$ 3,8. Uzorci su filtrirani PTFE membranama promjera pora $0,45 \mu \mathrm{m}$ te je UV/Vis analizom određena koncentracija LRS HCl u svakom vremenu uzorkovanja pri valnoj duljini od $314,2 \mathrm{~nm}$. Prikazani rezultati srednja su vrijednost dvaju provedenih ispitivanja. Programskim dodatkom DDSolver analizirani su profili oslobađanja lurasidon-hidroklorida iz raspadljivih tableta.

\section{Rezultati i rasprava}

\subsection{Rezultati karakterizacije čvrstih disperzija}

\subsubsection{Rezultati dobiveni diferencijalnom} pretražnom kalorimetrijom
Provedbom DSC toplinske analize čistih komponenti, kao i čvrstih disperzija LRS $\mathrm{HCl}$, dobiven je uvid u karakteristične fazne prijelaze svojstvene kristalnim, odnosno amorfnim tvarima. Oni ukazuju na toplinsko ponašanje, stabilnost te potencijalne interakcije komponenti u ispitivanim uzorcima.

Endotermni prijelaz taljenja poli(etilen-glikola) $\mathrm{s}$ minimumom pri $62{ }^{\circ} \mathrm{C}$ te staklište HPMC-a detektirano pri $167{ }^{\circ} \mathrm{C}$ u skladu su s literarnim navodima. ${ }^{14}$ Snimanje toplinskog ponašanja PEG-a započeto je u području niskih temperatura (od $-40{ }^{\circ} \mathrm{C}$ ) s ciljem detektiranja njegova staklastog prijelaza ${ }^{15}$ budući da je taj polimer definiran kao polukristalna tvar, no on nije uočen. Iz priloženog termograma kristalnog LRS $\mathrm{HCl}$-a (slika 1c) uočava se endotermni prijelaz od $\sim 280$ do $\sim 300{ }^{\circ} \mathrm{C} \mathrm{s}$ minimumima pri 285 i $290{ }^{\circ} \mathrm{C}$ koji odgovaraju taljenju LRS HCl. Širok endotermni prijelaz iznad $300{ }^{\circ} \mathrm{C}$ posljedica je njegove toplinske razgradnje. Drugi ciklus zagrijavanja DSC mjerenja proveden je pri istim uvjetima te $u$ istom temperaturnom području.
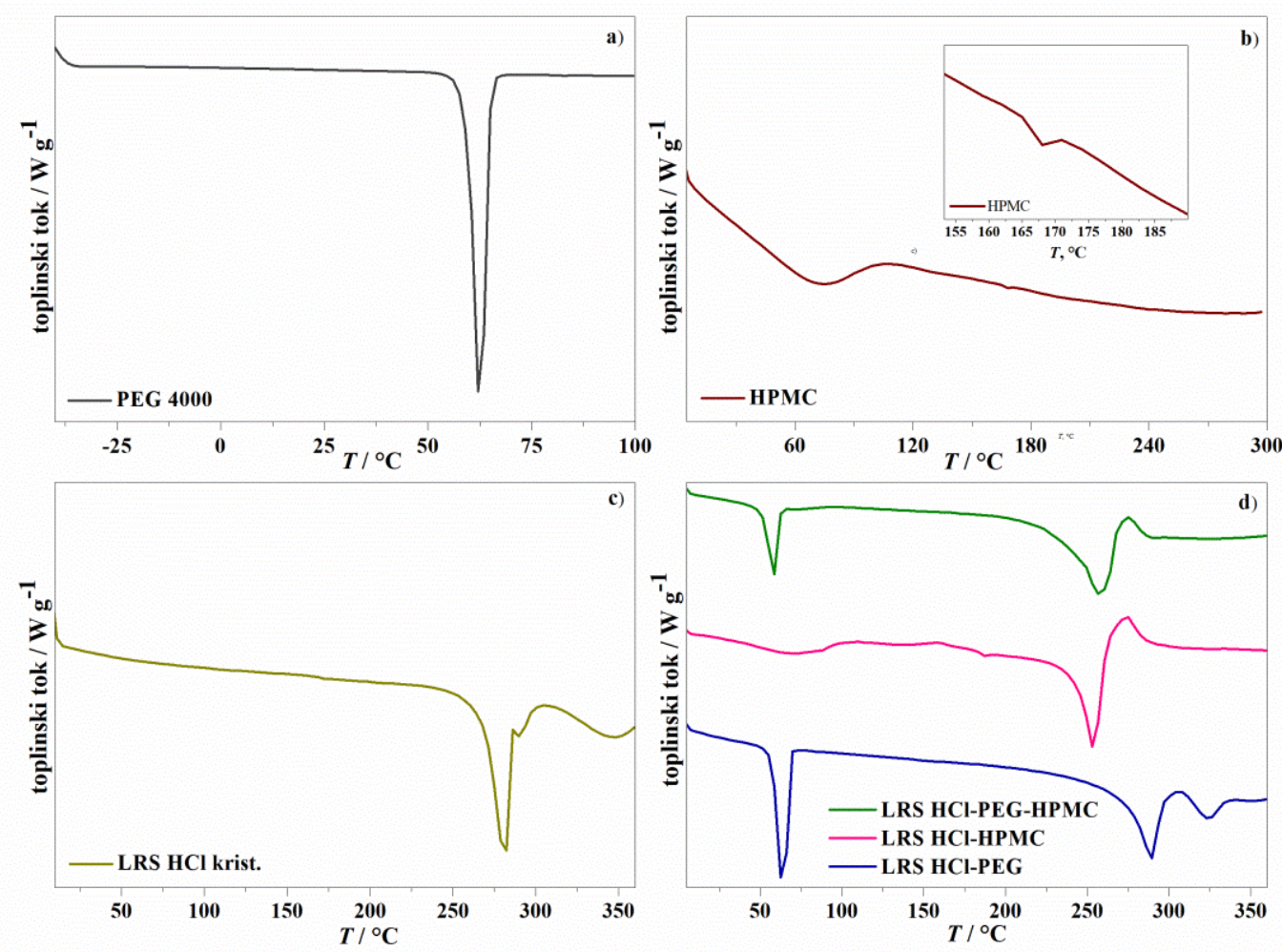

Slika 1 - DSC termogrami čistih komponenti (a), b) i c)) i čvrstih disperzija (d))

Fig. 1 - DSC thermograms of pure components (a), b) i c)), and solid dispersions (d)) 
Prijelazi svojstveni LRS HCl (taljenje) nisu uočeni, čime je potvrđena toplinska razgradnja djelatne tvari. Budući da nisu primijenjeni u evaluaciji, drugi ciklusi zagrijavanja nisu prikazani u okviru ovog rada. Spomenuti fazni prijelazi vidljivi su u pripravljenim čvrstim disperzijama (slika 1d), a njihov intenzitet ovisi o sastavu pojedinih uzoraka.

Uočava se značajan pomak tališta LRS HCl prema nižim temperaturama u disperzijama koje u svojem sastavu imaju HPMC (tablica 3). Taljenje djelatne tvari na nižim temperaturama može biti posljedica otapanja djelatne tvari $\mathrm{u}$ amorfnom polimeru za vrijeme provedbe mjerenja i/ili indikacija potencijalnih interakcija dviju komponenti. Nakon taljenja djelatne tvari dolazi do njezine razgradnje, također pri nižim temperaturama, iz čega se zaključuje da u čvrstim disperzijama s HPMC-om dolazi do smanjenja toplinske stabilnosti kristalita LRS HCl.

Dodatno, iz krivulje zagrijavanja čistog HPMC-a, kao i čvrste disperzije LRS HCl-HPMC, uočava se širok endotermni prijelaz od $\sim 40{ }^{\circ} \mathrm{C}$ do $\sim 100{ }^{\circ} \mathrm{C}$ koji odgovara uklanjaju adsorbirane vlage. Posljedica je to izrazite higroskopnosti te vrste polimera.

Nije uočen značajan pomak temperature taljenja djelatne tvari u čvrstoj disperziji LRS HCl-PEG (tablica 3). Isto tako, ne dolazi do promjene njegove toplinske stabilnosti budući da djelatna tvar u ovom slučaju toplinski degradira na temperaturama od 300 do $350{ }^{\circ} \mathrm{C}$, što je istovjetno toplinskom ponašanju čistog LRS HCl (slika 1c). Zaključuje se da djelatna tvar nije otopljena u rastaljenom polimeru uslijed provedbe mjerenja.

Tablica 3 - Detektirana toplinska svojstva ispitivanih uzoraka Table 3 - Detected thermal properties of the analysed samples

\begin{tabular}{|l|c|c|c|c|}
\hline $\begin{array}{l}\text { Uzorak } \\
\text { Sample }\end{array}$ & $T_{\mathrm{m} 1}(\mathrm{LRS})$ & $T_{\mathrm{m} 2}$ (LRS) & $T_{\mathrm{m}}$ (PEG) & $T_{\mathrm{g}}$ (HPMC) \\
\hline LRS HCl & $/{ }^{\circ} \mathrm{C}$ & $/{ }^{\circ} \mathrm{C}$ & $/{ }^{\circ} \mathrm{C}$ & $/{ }^{\circ} \mathrm{C}$ \\
\hline PEG 4000 & 285 & 291 & - & - \\
\hline HPMC E-6 & - & - & 62 & - \\
\hline LRS HCl-PEG & 290 & 293 & 61 & - \\
\hline LRS HCl-HPMC & 252 & 257 & - & 184 \\
\hline LRS & 257 & 264 & 59 & 171 \\
\hline HCl-PEG-HPMC & & & & -
\end{tabular}

\subsubsection{Rezultati dobiveni infracrvenom spektroskopijom s Fourierovom transformacijom}

FTIR spektroskopija primijenjena je s ciljem detektiranja potencijalnih interakcija između djelatne tvari i polimernih matrica. U slučaju postojanja interakcija, najčešće vezivanja vodikovom vezom, pomak apsorpcijskih vrpci specifičnih za funkcionalne skupine koje sudjeluju u interakciji trebao bi biti vidljiv. ${ }^{16}$

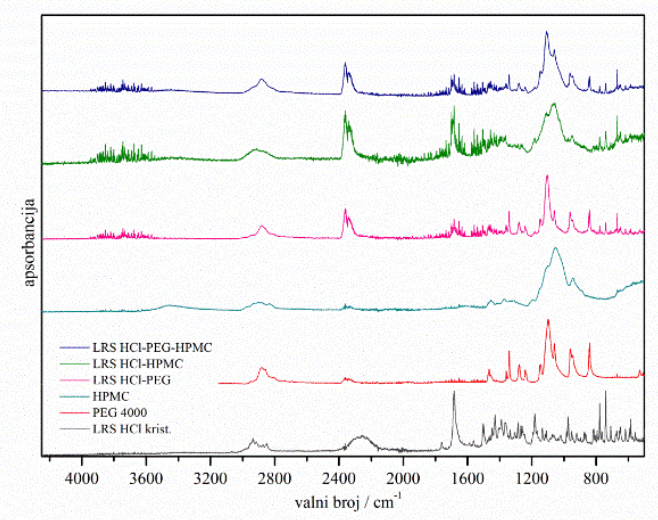

Slika 2 - FTIR spektri ishodnih komponenti i čvrstih disperzija

Fig. 2 - FTIR spectra of initial components and prepared solid dispersions

FTIR spektar LRS HCl pokazuje karakteristične apsorpcijske vrpce na $1684,13 \mathrm{~cm}^{-1}$ (C=O rastezanje), $1501,88 \mathrm{~cm}^{-1}$ $\left(\mathrm{C}=\mathrm{C}\right.$ rastezanje $\mathrm{u}$ aromatskom prstenu) te $2253,06 \mathrm{~cm}^{-1}$ $(\mathrm{N}-\mathrm{H}$ rastezanje), dok se u spektru PEG-a uočavaju karakteristične apsorpcijske vrpce na $2883,71 \mathrm{~cm}^{-1}$ (rastezanje $\mathrm{C}-\mathrm{H}$ veze unutar $\mathrm{O}-\mathrm{CH}_{2}$ skupine) i $1098,33 \mathrm{~cm}^{-1}$ (C-O-C rastezanje). Spektar HMPC-a pokazuje apsorpcijske vrpce na $1053,00 \mathrm{~cm}^{-1}(\mathrm{C}-\mathrm{O}-\mathrm{C}$ rastezanje) i $944,52 \mathrm{~cm}^{-1}$ (C-O-C veza u prstenu piranoze). Također, uočava se široka apsorpcijska vrpca u rasponu od 4000 do $3000 \mathrm{~cm}^{-1}$, području karakterističnom za $-\mathrm{OH}$ funkcionalnu skupinu. Široka apsorpcijska vrpca može ukazivati na stvaranje vodikove veze između hidroksilne skupine polimera i karbonilne skupine lurasidon-hidroklorida, ali vjerojatno je posljedica adsorbirane vlage. Navedeno je u skladu s rezultatima dobivenima DSC analizom, gdje je uočen širok endotermni prijelaz svojstven uklonjenoj vlazi.

Karbonilna skupina u molekuli LRS $\mathrm{HCl}$ potencijalni je akceptor vodikove veze, a u svim pripravljenim čvrstim disperzijama nije vidljiv pomak kao ni širenje te apsorpcijske vrste $\left(1684,13 \mathrm{~cm}^{-1}\right)$. Zaključuje se da nije došlo do vezivanja vodikovom vezom, što može biti posljedica viskoznosti upotrijebljenih polimera koja ograničava molekularnu mobilnost komponenti, a time smanjuje i mogućnost uspostave interakcija. ${ }^{17}$

\subsubsection{Rezultati dobiveni rendgenskom difrakcijskom analizom praha}

$\mathrm{Na}$ difraktogramima dobivenim rendgenskom difrakcijskom analizom uočavaju se oštri difrakcijski maksimumi lurasidon-hidroklorida. Maksimumi pri vrijednostima kuta difrakcije $(2 \theta)$ od $15,20^{\circ}, 17,18^{\circ}, 19,58^{\circ}$ i $22,00^{\circ}$ (slika 3) potvrđuju prisutnost kristaliničnog oblika LRS HCl u svim črrstim disperzijama, dok se u uzorku LRS HCl-PEG uočavaju i difrakcijski maksimumi polimera pri $19,10^{\circ}$ i $23,10^{\circ}$. Difraktogramom HPMC-a potvrđena je 
njegova amorfna struktura. Smanjeni intenziteti difrakcijskih maksimuma u odnosu na difraktograme čistih komponenti posljedica su manjeg udjela djelatne tvari u čvrstim disperzijama. Zaključuje se da liofilizacijom pripravljenih otopina djelatne tvari i polimera nije ostvarena promjena njihovog faznog sastava.

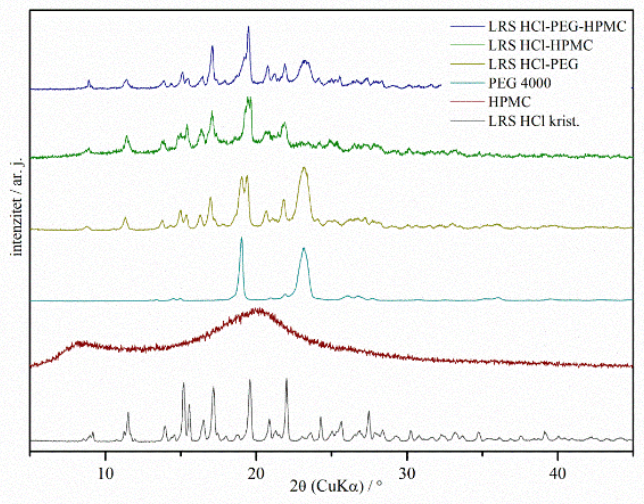

Slika 3 - Difraktogrami čistih komponenti i pripravljenih čvrstih disperzija

Fig. 3 - Diffractograms of pure components and prepared solid dispersions

\subsection{Rezultati dobiveni karakterizacijom raspadljivih tableta}

\subsubsection{Rezultati ispitivanja ujednačenosti masa, tvrdoća i raspadljivosti tableta}

Ujednačenost masa bitan je parametar kvalitete u pripravi tableta. Masa je određena dimenzijama matrice uređaja za tabletiranje kao i dubinom te jednolikošću njezina punjenja. Ujednačenost masa iskazana je kvantitativno, srednjom vrijednošću mase deset tableta te standardnom devijacijom kojoj je centralna tendencija aritmetička srednja masa tableta (tablica 4).

Tablete bez čvrstih disperzija imaju najbolju ujednačenost masa, što je posljedica izvrsne tecivosti uzorka te, posljedično, ravnomjernog punjenja matrice za tabletiranje. Mase tableta LRS HCl-PEG bliskije su ciljanoj vrijednosti (200 mg) i znatno su ujednačenije u odnosu na tablete pripravljene isključivo s HPMC-om. Međutim, veći udjel PEG-a u mješavini za tabletiranje uzrokuje izrazito lijepljenje za elemente uređaja za tabletiranje, što rezultira nastankom tableta s izraženim nepravilnostima. Takve tablete nezadovoljavajućih su primjenskih svojstava. Tablete LRS HCl-HPMC imaju najmanju srednju vrijednost masa, $\left(m_{\mathrm{sr}}=143,01 \mathrm{mg}\right.$ ) te najveće odstupanje od srednje vrijednosti, $s(s=9,32)$. Izvjesno je da struktura i velika molekulska masa HPMC-a ima nepovoljan učinak na tecivost mješavina za tabletiranje. Iz navedenih razloga pripravljena je ternarna čvrsta disperzija LRS HCl-a koja sadrži oba upotrijebljena polimera $\mathrm{i}$ to $\mathrm{u}$ istim masenim udjelima. Primjenom takve čvrste disperzije u pripravi mješavine za tabletiranje dobivene su tablete ujednačenih masa i bez strukturnih nepravilnosti.

Tvrdoća tablete ovisi o veličini i raspodjeli veličina čestica u mješavini za tabletiranje, o njezinoj gustoći i poroznosti, dubini punjenja matrice, veličini $\mathrm{i}$ obliku tablete te $\mathrm{o}$ primijenjenom tlaku kompresije. Tablete LRS HCl-PEG nisu podvrgnute ovom ispitivanju. Ponovljive i vjerodostojne rezultate nije bilo moguće ostvariti zbog postojanja ranije spomenutih strukturnih defekata. Srednja

Tablica 4 - Ujednačenost masa tableta

Table 4 - Uniformity of tablet mass

\begin{tabular}{|c|c|c|c|c|}
\hline $\begin{array}{l}\text { Uzorak } \\
\text { Sample }\end{array}$ & $\begin{array}{l}\text { Tablete bez čvrstih disperzija/mg } \\
\text { Tablets without solid dispersions/mg }\end{array}$ & $\begin{array}{c}\text { Tablete } \\
\text { LRS-PEG/mg } \\
\text { Tablets } \\
\text { LRS-PEG/mg }\end{array}$ & $\begin{array}{c}\text { Tablete } \\
\text { LRS-HPMC/mg } \\
\text { Tablets } \\
\text { LRS-HPMC/mg }\end{array}$ & $\begin{array}{c}\text { Tablete } \\
\text { LRS-PEG-HPMC/mg } \\
\text { Tablets } \\
\text { LRS-PEG-HPMC/mg }\end{array}$ \\
\hline 1. & 197,70 & 181,40 & 154,80 & 171,50 \\
\hline 2. & 196,20 & 177,20 & 148,60 & 167,20 \\
\hline 3. & 195,40 & 178,80 & 150,00 & 171,30 \\
\hline 4. & 196,10 & 180,70 & 138,90 & 171,60 \\
\hline 5. & 196,30 & 184,30 & 140,50 & 167,90 \\
\hline 6. & 195,70 & 184,80 & 121,10 & 164,40 \\
\hline 7. & 196,50 & 183,40 & 146,90 & 171,50 \\
\hline 8. & 196,30 & 181,60 & 142,40 & 167,60 \\
\hline 9. & 197,70 & 183,40 & 151,50 & 172,30 \\
\hline 10. & 195,00 & 179,20 & 135,40 & 166,00 \\
\hline$m_{\mathrm{sr}} / \mathrm{mg}$ & 196,29 & 181,48 & 143,01 & 169,13 \\
\hline $\mathrm{s} / \mathrm{mg}$ & 0,83 & 2,40 & 9,32 & 2,68 \\
\hline
\end{tabular}


vrijednost tvrdoće tableta LRS HCl-HPMC-PEG iznosi $57,13 \mathrm{~N}$, a za tablete LRS HCl-HPMC 19,50 N.

Raspadljivost tableta definirana je kao vrijeme unutar kojeg se tablete moraju razložiti na mnoštvo sitnih dijelova koji prolaze kroz žičano sito uređaja. Europska farmakopeja nudi definiciju prema kojoj se tableta naziva raspadljivom ukoliko se unutar $180 \mathrm{~s}$ u potpunosti raspadne u usnoj šupljini $\mathrm{i}$ to bez primjene vode. ${ }^{5}$ Rezultati ispitivanja raspadljivosti tableta prikazani u tablici 5 pokazuju da sve tablete udovoljavaju navedenoj definiciji, jer je $t_{\mathrm{sr}}$ svih tableta kraće od $180 \mathrm{~s}$. Najkraće vrijeme raspada te najbolju ujednačenost vremena raspada imaju tablete sustava LRS HCl-PEG-HPMC. Prikazane vrijednosti u suprotnosti su s rezultatima ispitivanja tvrdoće budući da se očekuje da će se tablete manje tvrdoće (LRS-HPMC) raspasti u kraćem vremenu. ${ }^{18}$ Zaključuje se da postoji značajan utjecaj vrste kao i udjela ispitivanih polimera na svojstva konačnog dozirnog oblika. Tablete pripravljene kombinacijom dvaju polimera različitog faznog sastava (polukristalni PEG i amorfni HPMC) imaju najkraća i najujednačenija vremena raspada, kao i najujednačenije mase, što je vidljivo iz vrijednosti prikazanih u tablicama 4 i 5 .

Tablica 5 - Rezultati ispitivanja raspadljivosti tableta

Table 5 - Disintegration test results of the tablets

\begin{tabular}{l|ccc} 
& Tablete & Tablete & Tablete \\
& LRS-PEG & LRS-HPMC & LRS-PEG-HPMC \\
& Tablets & Tablets & Tablets \\
& LRS-PEG & LRS-HPMC & LRS-PEG-HPMC \\
\hline$t_{\mathrm{sr}} / \mathrm{s}$ & 89 & 161 & 85 \\
\hline $\mathrm{s} / \mathrm{s}$ & 45 & 62 & 9 \\
\hline
\end{tabular}
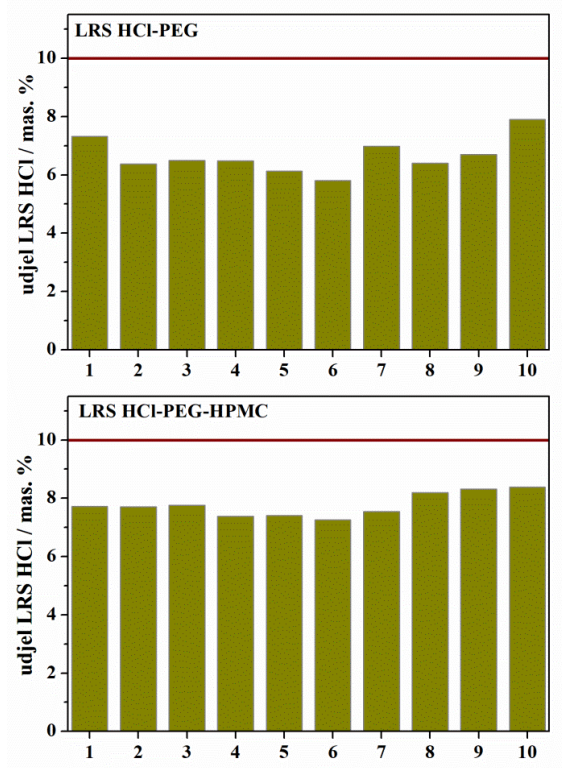

\subsubsection{Određivanje sadržaja djelatne tvari UV-Vis spektrofotometrijskom metodom}

Ciljani sadržaj LRS HCl (10 mas. \%) nije ostvaren ni u jednoj od tri formulacije tableta. Unatoč tome, iz prikazanih rezultata (slika 4) uočavaju se značajne razlike u svojstvima pripravljenih tableta. Najbolja ujednačenost sadržaja djelatne tvari ostvarena je u tabletama koje sadrže Čvrstu disperziju sastava LRS HCl-PEG-HPMC $(s=0,38)$, što je u skladu s rezultatima određivanja ujednačenosti masa. Upravo je u tim tabletama srednja vrijednost detektiranog sadržaja LRS $\mathrm{HCl}(7,77$ mas. \% LRS $\mathrm{HCl})$ najbliža ciljanoj (10 mas. \% LRS $\mathrm{HCl}$ ). Odstupanje detektirane od ciljane vrijednosti vjerojatno je posljedica loše homogenosti mješavine za tabletiranje. Neujednačenost veličina čestica dvaju prašaka (čvrsta disperzija i granulat pomoćnih tvari) uzrokuje segregaciju čestica uslijed punjenja matrice uređaja za tabletiranje. ${ }^{19}$ Izgledno je da sitnije čestice (čvrsta disperzija) zaostanu unutar sustava za doziranje i time uzrokuju nejednoliko punjenje matrice.

\subsubsection{Analiza oslobađanja djelatne tvari}

Brzina oslobađanja LRS $\mathrm{HCl}$ znatno je veća iz tableta u kojima je djelatna tvar formulirana u obliku čvrstih disperzija u odnosu na one $u$ kojem se nalazi u izvornom obliku (LRS HCl krist.), gdje je nakon 120 min otopljeno $20,9 \%$ inicijalne mase djelatne tvari. Vrsta polimera značajno utječe na brzinu i doseg otapanja djelatne tvari. Čvrstom disperzijom LRS HCl-HPMC ostvaruje se kontrolirano oslobađanje djelatne tvari, što je posljedica umrežene strukture polimera. Brzina oslobađanja LRS HCl pod kontrolom je kinetike bubrenja HPMC-a te ovisi o

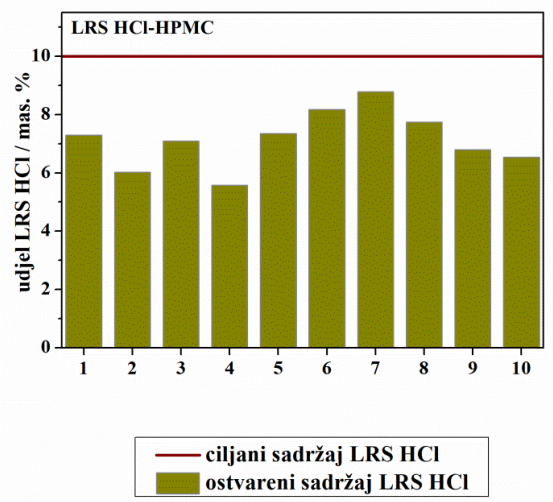

Vrijednosti standardne devijacije, $s$ :

LRS-PEG $\quad s=0,57$

LRS-HPMC $\quad s=0,92$

LRS-PEG-HPMC $\quad s=0,38$

Slika 4 - Ujednačenost sadržaja LRS HCl u raspadljivim tabletama za usta uz prikaz odstupanja od ciljane vrijednosti Fig. 4 - Content uniformity of LRS HCl in orally disintegrating tablets with a display of deviation from targeted value 
propusnosti djelatne tvari kroz sloj otopljenog polimera. ${ }^{20}$ $\mathrm{S}$ druge strane, primjenom PEG-a (tablete LRS HCl-PEG) ostvareno je potpuno oslobađanje djelatne tvari nakon 120 min. Isto tako, te tablete udovoljavaju definiciji tableta s trenutnim oslobađanjem europske farmakopeje budući da je 81,0 \% početne mase LRS HCl otopljeno već nakon 20 min. Uzrok tome može biti poboljšano kvašenje djelatne tvari i solubilizacijski učinak PEG-a, ali i smanjenje veličina čestica djelatne tvari uslijed liofilizacije. ${ }^{21}$ Pripravom ternarne čvrste disperzije kombinacijom PEG-a i HPMC-a ostvareno je najmanje odstupanje među dvama provedenim mjerenjima, što je posljedica ujednačenosti sadržaja LRS HCl. Nakon 120 min otopljeno je više od 85 \% inicijalne mase LRS HCl, naspram 60,1\% oslobođenih kod tableta koje sadrže disperziju sastava LRS HCl-HPMC. Rezultati pokazuju da simultana primjena tih dvaju polimera u pripremi ternarnih Čvrstih disperzija LRS $\mathrm{HCl}$ pokazuje daljnji istraživački potencijal. Promjenom udjela ispitivanih polimera može se utjecati na daljnji porast brzine oslobađanja djelatne tvari, uz zadržavanje dobrih svojstava pripravljenih tableta.

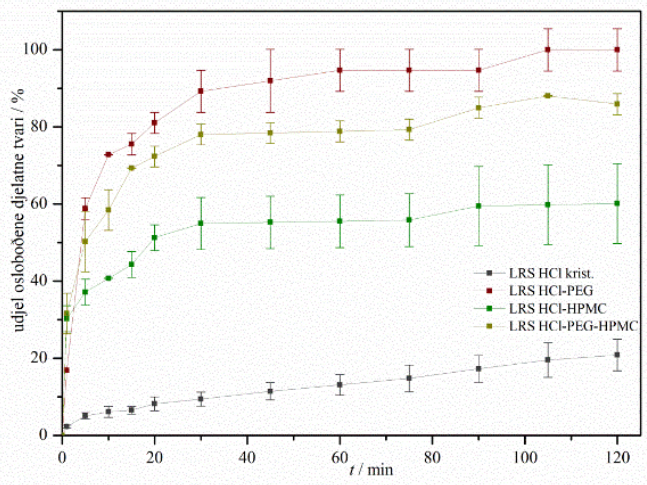

Slika 5 - Profili oslobađanja LRS HCl iz tableta koje sadrže Čvrste disperzije te čistu djelatnu tvar

Fig. 5 - Release profiles of LRS HCl from tablets containing solid dispersions and pure drug

\section{Zaključak}

Primjena liofilizacije u svrhu priprave čvrstih disperzija pokazala se opravdanom budući da je u svim pripravljenim formulacijama ostvaren značajan porast brzine oslobađanja djelatne tvari. Značaj ove studije tim je veći što do sada u literaturi nisu objavljena istraživanja u kojima su čvrste disperzije lurasidon-hidroklorida pripravljene postupkom liofilizacije. Raspadljive tablete za usta primjeren su dozirni oblik za primjenu te vrste djelatne tvari, a njihova svojstva uvelike ovise o vrsti i karakteristikama primijenjenih polimera. Kombinacijom dvaju polimera s ciljem razvoja ternarnih čvrstih disperzija lijeka moguće je pripraviti raspadljive tablete za usta dobrih primjenskih svojstava i znatno većih brzina oslobađanja djelatne tvari u odnosu na čistu djelatnu tvar.

\section{Popis simbola \\ List of symbols}

$$
\begin{aligned}
m_{\mathrm{sr}} & - \text { srednja vrijednost mase, } \mathrm{g} \\
& - \text { mean mass value, } \mathrm{g} \\
\mathrm{s} & - \text { standardna devijacija } \\
& - \text { standard deviation } \\
t & - \text { vrijeme, } \mathrm{s} \\
& - \text { time, } \mathrm{s} \\
T & - \text { temperatura, }{ }^{\circ} \mathrm{C} \\
& - \text { temperature, }{ }^{\circ} \mathrm{C} \\
T_{\mathrm{g}} & - \text { temperatura staklastog prijelaza, }{ }^{\circ} \mathrm{C} \\
& - \text { glass transition temperature, }{ }^{\circ} \mathrm{C} \\
T_{\mathrm{m}} & - \text { temperatura taljenja, }{ }^{\circ} \mathrm{C} \\
& - \text { melting temperature, }{ }^{\circ} \mathrm{C} \\
t_{\mathrm{sr}} & - \text { srednje vrijeme, } \mathrm{s} \\
& - \text { mean time, } \mathrm{s} \\
\lambda & - \text { valna duljina, nm } \\
& - \text { wavelength, nm } \\
\theta & - \text { difrakcijski kut, }{ }^{\circ} \\
& - \text { diffraction angle, }{ }^{\circ}
\end{aligned}
$$

\begin{tabular}{|c|c|}
\hline DSC & - diferencijalna pretražna kalorimetrija \\
\hline FDA & $\begin{array}{l}\text { - Američka agencija za hranu i lijekove } \\
\text { - Food and Drug Administration }\end{array}$ \\
\hline FTIR & $\begin{array}{l}\text { - Infracrvena spektroskopija s Fourierovom } \\
\text { transformacijom } \\
\text { - Fourier Transform Infrared Spectroscopy }\end{array}$ \\
\hline HPMC & $\begin{array}{l}\text { - hidroksipropil-metil-celuloza } \\
\text { - hydroxypropyl methylcellulose }\end{array}$ \\
\hline LRS HCl & $\begin{array}{l}\text { - lurasidon-hidroklorid } \\
\text { - lurasidone hydrochloride }\end{array}$ \\
\hline MAN & $\begin{array}{l}\text { - manitol } \\
\text { - mannitol }\end{array}$ \\
\hline MCC & $\begin{array}{l}\text { - mikrokristalna celuloza } \\
\text { - microcrystalline cellulose }\end{array}$ \\
\hline NKK & $\begin{array}{l}\text { - natrijeva kroskarmeloza } \\
\text { - croscarmellose sodium (CCS) }\end{array}$ \\
\hline ODTs & $\begin{array}{l}\text { - raspadljive tablete za usta } \\
\text { - orally disintegrating tablets }\end{array}$ \\
\hline PEG & $\begin{array}{l}\text { - poli(etilen-glikol) } \\
\text { - polyethylene glycol }\end{array}$ \\
\hline Ph. Eur. & $\begin{array}{l}\text { - Europska farmakopeja } \\
\text { - European pharmacopeia }\end{array}$ \\
\hline SAD & $\begin{array}{l}\text { - Sjedinjene Američke Države } \\
\text { - United States of America }\end{array}$ \\
\hline USP & $\begin{array}{l}\text { - američka farmakopeja } \\
\text { - United States pharmacopeia }\end{array}$ \\
\hline UV/Vis & $\begin{array}{l}\text { - ultraljubičast/vidljiv } \\
\text { - ultraviolet/visible }\end{array}$ \\
\hline XRPD & $\begin{array}{l}\text { - rendgenska difrakcija na praškastom uzorku } \\
\text { - X-ray powder diffraction }\end{array}$ \\
\hline
\end{tabular}

\section{Popis kratica List of abbreviations}




\section{Literatura}

\section{References}

1. URL:

https://www.plivazdravlje.hr/aktualno/clanak/8986/Razumjet i-shizofreniju.html (6. 3. 2020.).

2. URL:

https://www.zdravobudi.hr/clanak/232/antipsihotici (6. 3. 2020.).

3. C. Cecchi, P. L. Canonico, Formulazioni farmaceutiche e aderenza al trattamento farmacologico in psichiatria: l'esempio della formulazione orodispersibile di olanzapina, Riv. Psichiatr. 47 (2012) 30-39, doi: https://doi.org/10.1708/1034.11289.

4. URL:

https://www.fda.gov/media/70877/download (6. 3. 2020.).

5. European Pharmacopoeia, $5^{\text {th }}$ Ed., Council of Europe, Strasbourg, 2006., str. 628.

6. M. Ankit, Y. Manish, C. Dinesh, S. Birendra, Enhancement of solubility of lurasidone hydrochloride using solid dispersion technique, Int. J. Res. Ayurveda Pharm. 5 (2014) 632-637, doi: https://doi.org/10.7897/2277-4343.055129.

7. J. R. Madan, K. T. Pawar, K. Dua, Solubility enhancement studies on lurasidone hydrochloride using mixed hydrotropy, Int. J. Pharm. Investig. 5 (2015) 114-120, doi: https://dx.doi.org/10.4103\%2F2230-973X.153390.

8. K. T. Savjani, A. K. Gajjar, J. K. Savjani, Review article drug solubility: Importance and enhancement techniques, ISRN Pharm. 2012 (2012), doi: https://doi.org/10.5402/2012/195727.

9. S. Gurunatha, S. P. Kumar, N. K. Basavaraj, P. A. Patil, Amorphous solid dispersion method for improving oral bioavailability of poorly water-soluble drugs, J. Pharm. Res. 6 (2013) 476-480, doi: https://doi.org/10.1016/j.jopr.2013.04.008.

10. Y. Huang, W. G. Dai, Fundamental aspects of solid dispersion technology for poorly soluble drugs, Acta Pharm. Sin. B. 4 (2014) 18-25, doi: https://doi.org/10.1016\%2Fj.apsb.2013.11.001.

11. N. Saffoon, R. Uddin, N. H. Huda, K. Bishwajit Sutradhar, Enhancement of oral bioavailability and solid dispersion: A review, J. App. Pharm. Sci. 1 (2011) 13-20.

12. M. Gretić, Utjecaj sastava mješavina na svojstva gotovih tableta, Diplomski rad, Fakultet kemijskog inženjerstva i tehnologije Sveučilišta u Zagrebu, 2015., str. 43.
13. URL:

http://202.195.214.45/yaodian/ep/EP5.0/02_methods_of_an alysis/2.9._pharmaceutical_technical_procedures/2.9.1.\%2 0Disintegration\%20of\%20tablets\%20and\%20capsules.pdf (6. 3. 2020.).

14. J. S. LaFountaine L. K. Prasad, C. Brough, D. A. Miller, J. W. McGinity, R. O. III Williams, Thermal processing of PVP- and HPMC-based amorphous solid dispersions, AAPS Pharm. Sci. Tech. 17 (2016) 120-132, doi: https://doi.org/10.1208/s12249-015-0417-7.

15. A. A. D'souza, A. Anisha, R. Shegokar, Polyethylene glycol (PEG): A versatile polymer for pharmaceutical applications, Expert Opin. Drug Del. 13 (2016) 1257-1275, doi: http://doi.org/10.1080/17425247.2016.1182485.

16. I. Škorić, Molekulska spektroskopija - nastavni tekst, Fakultet kemijskog inženjerstva i tehnologije Sveučilišta u Zagrebu, str. 3-7.

17. J. O. Eloy, J. M. Marchetti, Solid dispersions containing ursolic acid in poloxamer 407 and PEG 6000: A comparative study of fusion and solvent methods, Powder Technol. 253 (2014) 98-106, doi: https://doi.org/10.1016/j.powtec.2013.11.017.

18. A. F. Marais, M. Song, M. M. de Villiers, Effect of compression force, humidity and disintegrant concentration on the disintegration and dissolution of directly compressed furosemide tablets using croscarmellose sodium as disintegrant, Trop. J. Pharm. Res. 2 (2003) 125-135, doi: https://doi.org/10.4314/tjpr.v2i1.14577.

19. D. Mateo-Ortiz, Daniel, F. J. Muzzio, R. Méndez, Particle size segregation promoted by powder flow in confined space: The die filling process case, Powder Technol. 262 (2014) 215222, doi: https://doi.org/10.1016/j.powtec.2014.04.023.

20. H. A. Hameed, S. Khan, M. Shahid, R. Ullah, A. Bari, S. S. Ali, Z. Hussain, M. Sohail, S. U. Khan, T. T. Htar, Engineering of naproxen loaded polymer hybrid enteric microspheres for modified release tablets: Development, characterization, in silico modelling and in vivo evaluation, Drug. Des. Dev. Ther. 2020 (2020) 27-41, doi: http://doi.org/10.2147/DDDT.S232111.

21. L. Barghi, A. Farajzadeh, A. Jahangiri, Preparation and evaluation of glibencladmide binary solid dispersions prepared by fusion and solvent-fusion method, Biointerface Res. Appl. Chem. 9 (2019) 4612-4616, doi: https://doi.org/10.33263/BRIAC96.612616. 


\title{
SUMMARY
}

\section{Release Rate Enhancement of Lurasidone Hydrochloride from Orally Disintegrating Tablets using Lyophilisation}

\author{
Josipa Skočibušić, Joško Barbarić, and Krunoslav Žižek
}

This paper investigates the possibilities for release rate enhancement of lurasidone hydrochloride, a second-generation antipsychotic, by preparing solid dispersions via lyophilisation process. FTIR, DSC, and XRPD measurements have been performed in order to detect potential interactions between lurasidone hydrochloride and polymer matrices that might significantly increase drug solubility and provide faster release from the dosage form. Such solid dispersions and excipients have been used in the preparation of tablets that disintegrate in less than $3 \mathrm{~min}$. In vitro dissolution profiles indicate a higher drug release rate from disintegrating tablets in comparison to pure LRS $\mathrm{HCl}$.

\section{Keywords}

Lurasidone hydrochloride, solid dispersion, lyophilisation, orally disintegrating tablet, drug release

Faculty of Chemical Engineering and Technology

Original scientific paper

University of Zagreb

Received April 15, 2020

Marulićev trg 19

Accepted July 2, 2020

10000 Zagreb, Republic of Croatia 